\title{
Grand Challenges in the immunology of HIV and AIDS
}

\section{Frank Miedema*}

Department of Immunology, University Medical Centre Utrecht, Utrecht, Netherlands

${ }^{*}$ Correspondence: f.miedema@umcutrecht.nl

\section{INTRODUCTION}

After the first reports of patients with AIDS in 1981, the discovery in 1983 of HIV as the etiological agent that causes AIDS and in 1984 of the CD4 protein as the main receptor for the virus our views on HIV pathology have been quite straightforward. Apparently HIV infects CD4+ human cells, which are mainly $\mathrm{T}$ helper cells, and in vitro studies show that these cells die in the course of a productive HIV infection. Thus, HIV is cytopathic for CD4+ T helper cells and this relates directly to very low CD4+ T helper cells in patients that present with AIDS symptoms and to the progressive loss of these cells in the course of HIV infection to AIDS. Indeed, in HIV infection the degree of depletion of CD4+ $\mathrm{T}$ cell numbers is since these days used as the main marker of disease progression (Fauci et al., 1996). This cytopathic model of AIDS pathogenesis has been boosted by two additional observations of very different kinds. First, Ho et al. (1995) showed the true viral dynamics of HIV infection, making it clear that even in asymptomatic individuals daily production of HIV is very high, at least in the order of 10 (Grossman et al., 2002) viral particles per day, with a RT error rate that creates HIV tremendous variation and allows for rapid escape from drug and immune pressure. In addition, these authors reported high CD4+ T cell death rates and compensatory production of these cells which exhausts the immune system eventually depleting CD4+ T cells, the cause of AIDS. Second, in 1996 formal molecular proof was reported for two distinct co-receptors of HIV (Cocchi et al., 1995; Feng et al., 1996) that explained the observation of HIV variants with different cytopathicity and with different cellular tropism (Tersmette et al., 1989; Koot et al., 1993; Connor et al., 1997). Although in both immunology and virology there were problems regarding this cytopathic account of HIV/AIDS, not in the least because of the lack of a better comprehensive model, until very recently it has been the dominant view in textbooks and the literature.

\section{CHRONIC INFLAMMATION DRIVES HIV ASSOCIATED DISEASE}

Our insights and ideas about AIDS pathogenesis have gradually but drastically changed over the past decade and it is now widely held that the direct cytopathic effects of HIV do not, but the chronic inflammation that HIV induces does explain progression to AIDS (Hazenberg et al., 2000; McCune, 2001; Grossman et al., 2002; Douek et al., 2003). This is based on the fact that progression to disease is better predicted by the level of immune activation. Various markers of adaptive and innate immune activation are better and independent prognostic markers than $\mathrm{CD} 4+\mathrm{T}$ cell numbers and viral load (Fahey et al., 1990; Giorgi et al., 1999; Hazenberg et al., 2003; Deeks et al., 2004). Furthermore, SIV monkey models strongly suggest that, even in the presence of high viral loads of cytopathic SIV, without chronic immune activation progression to disease is not observed, which corresponds to the rare non-progressing patients that have high viral loads (Silvestri et al., 2003). This has led to a view on HIV pathogenesis that is quite different from the classical cytopathic model and which has implications for therapy and vaccine development. The recent finding that inflammation in nonpathogenic SIV infection is actively down regulated by a gene expression program that is activated early after acute SIV infection prompts investigation into the mechanisms of that inhibitory gene expression and how it is started (Bosinger et al., 2009). In analogy, it will be key to understand why in humans in practically no infected individual an efficient and inhibitory gene expression profile is activated.

A first important insight from this development is that in HIV infection, immune deficiency is the result of chronic activation of both the adaptive and innate immune system and is not an immediate effect of HIV infection. HIV induces activation of virtually all leukocyte populations (Deeks, 2011) and in agreement with that in asymptomatic but even in late stage HIV infection strong cellular and humoral immune responses are mounted from which the virus escapes, already in the first weeks after HIV infection, irrespective of the HLA background of the host, the virus is under severe pressure of cytotoxic T lymphocytes (CTL; Goonetilleke et al., 2009; Fischer et al., 2010). Leukocyte activation is reflected in activated cells, expression, and massive release of pro-inflammatory cytokines. Evidence for adaptive response has been complemented by our more recent insights that HIV single stranded (ss) RNA directly activates the innate immune system via Toll like receptor (TLR) 7 and 8 in pDC and macrophages which causes the release of TNF alpha (Beignon et al., 2005; Meier et al., 2007). This has down-stream activating effects on NK, B cells, and CD4+ and CD8+ T cell and their turnover (Hardy et al., 2007). In addition, bacterial products, including LPS and peptidoglycans, translocating from the gut are implied in driving immune activation even further. Bacterial translocation results from HIV associated depletion of CD4+ T cells from gut mucosa which affects gut integrity important to contain microbes in the GI tract (Brenchley et al., 2006). Further investigation to understand the contribution of bacterial translocation to immune activation is warranted.

\section{NON-AIDS DISEASE ASSOCIATED WITH HIV INFECTION}

It is recognized that chronic inflammation underlies pathology in various clinical conditions, obviously in autoimmune diseases, IBD, and Crohn's disease, but also in atherosclerosis and cardiovascular disease (CVD), some neurological diseases and liver and kidney failure (Medzhitov, 2010). Although initially cardiovascular, liver, and kidney disease was believed to be associated with side effects of some antiviral drugs, more recently HIV induced inflammation is thought to be implied also in these non-AIDS diseases (Bozzette et al., 2003; El-Sadr et al., 2006). Although cART diminishes viral load and through that takes away most of the driver of inflammation, patients on long term cART have increased 
risk for CVD and other non-AIDS disease which is associated with residual immune activation (Jiang et al., 2009).

\section{THERAPY}

cART is effectively used for more than 15 years now and novel drugs targeting viral fusion are being developed and used. A serious problem is viral escape from antivirals and the transmission of drug-resistant variants, in developed and even more in developing countries were cART has been administered. Immune therapy by therapeutic vaccination has not been successful and may be questioned as we now realize that immune activation is detrimental and specific immune response are strong (Autran et al., 2008). It could be that the quality of CTL and neutralizing antibodies (NeuAb) which prevail in chronic infection may be insufficient for control of HIV which may be eligible for restoration and enhancement (Betts et al., 2006). Similarly, immune therapy such as with Il-7 has to be reconsidered because it activates the peripheral immune system (Sereti et al., 2009), although in combination with cART this may be an option. When immune activation is a driver of disease before and after cART, inhibition of the various TLRs, cytokine responses such as TNF alpha and other inflammation pathways has to be considered at least to deal with non-AIDS end organ diseases. Novel genetic analyses using large data sets, more sequence information and novel bioinformatics tools may help to define novel targets for therapeutic intervention in the immune system that are critical for disease progression or control of inflammation in HIV infected individuals. Finally it still remains the question whether the virus can be eradicated from an infected host and what type of therapy would be required for that.

\section{HIV SPECIFIC IMMUNITY AND HIV VACCINES}

HIV can effectively escape from CTL and NeuAb. Some CTL that are restricted by rare protective HLA, mainly B57, have been associated with a lower viral load set point that may be caused by CTL driven viral attenuation (Leslie and Goulder, 2006; Frater et al., 2007; Navis et al., 2007; Miura et al., 2010). Despite these effects, CTL do not appear to protect from disease progression (Schellens et al., 2008). Similarly, NeuAb drive escape but are not prognostic for time to AIDS (Bunnik et al., 2010; Euler et al., 2010). This does not preclude a protective role for vaccine induced prophylactic CTL or NeuAb. Since the STEP trial was stopped in 2007 because of a lack of effect on viral set point in vaccines after break through infection, vaccine development has been reevaluated. The concept of CTL based vaccines has been seriously questioned since it will not provide protection from infection and only temporarily slow down disease progression. Still, the idea of a CTL based vaccine has not been abandoned and encouraging and surprising results using a CMV based viral vector have just been reported in the SIV monkey model (Hansen et al., 2011). The field has at the same time seen a swing back to NeuAb and vaccine design based on the epitopes of broadly and potently $\mathrm{NeuAb}$ has been fueled by interesting novel $\mathrm{NeuAb}$ specificities that were recently reported (Wu et al., 2010; Zhou et al., 2010).

\section{REFERENCES}

Autran, B., Murphy, R. L., Costagliola, D., Tubiana, R., Clotet, B., Gatell, J., Staszewski, S., Wincker, N., Assoumou, L., El-Habib, R., Calvez, V., Walker, B. Katlama, C., and ORVACS Study Group. (2008). Greater viral rebound and reduced time to resume antiretroviral therapy after therapeutic immunization with the ALVAC-HIV vaccine (vCP1452). AIDS 22, 1313-1322.

Beignon, A. S., McKenna, K., Skoberne, M., Manches, O., DaSilva, I., Kavanagh, D. G., Larsson, M., Gorelick, R. J., Lifson, J. D., and Bhardwaj, N. (2005). Endocytosis of HIV-1 activates plasmacytoid dendritic cells via Toll-like receptor-viral RNA interactions. J. Clin. Invest. 115, 3265-3275.

Betts, M. R., Nason, M. C., West, S. M., De Rosa, S. C., Migueles, S.A., Abraham, J., Lederman, M. M., Benito, J. M., Goepfert, P. A., Connors, M., Roederer, M., and Koup, R.A. (2006). HIV nonprogressors preferentially maintain highly functional HIV-specific CD8+T cells. Blood 107, 4781-4789.

Bosinger, S. E., Li, Q., Gordon, S. N., Klatt, N. R., Duan, L., Xu, L., Francella, N., Sidahmed, A., Smith, A. J., Cramer, E. M., Zeng, M., Masopust, D., Carlis, J. V., Ran, L., Vanderford, T. H., Paiardini, M., Isett, R. B., Baldwin, D. A., Else, J. G., Staprans, S. I., Silvestri, G., Haase, A. T., and Kelvin, D. J. (2009). Global genomic analysis reveals rapid control of a robust innate response in SIV-infected sooty mangabeys. J. Clin. Invest. 119, 3556-3572.

Bozzette, S. A., Ake, C. F., Tam, H. K., Chang, S. W., and Louis, T.A. (2003). Cardiovascular and cerebrovascular events in patients treated for human immunodeficiency virus infection. N. Engl. J. Med. 348, 702-710.

Brenchley, J. M., Price, D. A., Schacker, T. W., Asher, T. E., Silvestri, G., Rao, S., Kazzaz, Z., Bornstein, E., Lambotte, O., Altmann, D., Blazar, B. R., Rodriguez, B., Teixeira-Johnson, L., Landay, A., Martin, J. N., Hecht, F. M., Picker, L. J., Lederman, M. M., Deeks, S. G., and Douek, D. C. (2006). Microbial translocation is a cause of systemic immune activation in chronic HIV infection. Nat. Med. 12, 1365-1371.

Bunnik, E. M., Euler, Z., Welkers, M. R., Boeser-Nunnink, B. D., Grijsen, M. L., Prins, J. M., and Schuitemaker, H. (2010). Adaptation of HIV-1 envelope gp120 to humoral immunity at a population level. Nat. Med. 16, 995-997.

Cocchi, F., DeVico, A. L., Garzino-Demo, A., Arya, S. K., Gallo, R. C., and Lusso, P. (1995). Identification of RANTES, MIP-1a, and MIP-1b as the major HIVsuppressive factors produced by CD8+ T cells. Science 270, 1811-1815.

Connor, R. I., Sheridan, K. E., Ceradini, D., Choe, S., and Landau, N. R. (1997). Change in coreceptor use correlates w0ith disease progression in HIV-1-infected individuals. J. Exp. Med. 185, 621-628.

Deeks, S. G. (2011). HIV infection, inflammation, immunosenescence, and aging. Annu. Rev. Med. 62, 141-155.

Deeks, S. G., Kitchen, C. M., Liu, L., Guo, H., Gascon, R., Narváez, A. B., Hunt, P., Martin, J. N., Kahn, J. O., Levy, J., McGrath, M. S., and Hecht, F. M. (2004). Immune activation set point during early HIV infection predicts subsequent CD4+ T-cell changes independent of viral load. Blood 104, 942-947.

Douek, D. C., Picker, L. J., and Koup, R. A. (2003). T cell dynamics in HIV-1 infection 14. Annu. Rev. Immunol. 21, 265-304.

El-Sadr, W. M. Lundgren, J. D., Neaton, J. D., Gordin, F., Abrams, D., Arduino, R. C., Babiker, A., Burman, W., Clumeck, N., Cohen, C. J., Cohn, D., Cooper, D., Darbyshire, J., Emery, S., Fätkenheuer, G., Gazzard, B., Grund, B., Hoy, J., Klingman, K., Losso, M., Markowitz, N., Neuhaus, J., Phillips, A., and Rappoport, C. (2006). CD4+ count-guided interruption of antiretroviral treatment. N. Engl. J. Med. 355, 2283-2296.

Euler, Z., van Gils, M. J., Bunnik, E. M., Phung, P., Schweighardt, B., Wrin, T., and Schuitemaker, H. (2010). Cross-reactive neutralizing humoral immunity does not protect from HIV type 1 disease progression. J. Infect. Dis. 201, 1045-1053.

Fahey, J. L., Taylor, J. M., Detels, R., Hofmann, B., Melmed, R., Nishanian, P., and Giorgi, J. V. (1990). The prognostic value of cellular and serologic markers in infection with human immunodeficiency virus type $1 . N$. Engl. J. Med. 322, 166-172.

Fauci, A. S., Pantaleo, G., Stanley, S., and Weissman, D. (1996). Immunopathogenic mechanisms of HIV infection. Ann. Intern. Med. 124, 654-663.

Feng, Y., Broder, C. C., Kennedy, P. E., and Berger, E. A. (1996). HIV-1 entry cofactor: functional cDNA cloning of a seven-transmembrane, $G$ protein-coupled receptor. Science 272, 872-877.

Fischer, W. Ganusov, V. V., Giorgi, E. E., Hraber, P. T., Keele, B. F., Leitner, T., Han, C. S., Gleasner, C. D., Green, L., Lo, C. C., Nag, A., Wallstrom, T. C., Wang, S., McMichael, A. J., Haynes, B. F., Hahn, B. H., Perelson, A. S., Borrow, P., Shaw, G. M., Bhattacharya, T., and Korber, B. T. (2010). Transmission of single HIV-1 genomes and dynamics of early immune escape revealed by ultra-deep sequencing. PLOS ONE 5, e12303. doi: 10.1371/journal.pone.0012303

Frater, A. J., Brown, H., Oxenius, A., Günthard, H. F., Hirschel, B., Robinson, N., Leslie, A. J., Payne, R., Crawford, H., Prendergast, A., Brander, C., Kiepiela, P., Walker, B. D., Goulder, P. J., and McLean, A, Phillips, R. E. (2007). Effective T-cell responses select human 
immunodeficiency virus mutants and slow disease progression. J. Virol. 81, 6742-6751.

Giorgi, J. V., Hultin, L. E., McKeating, J. A., Johnson, T. D., Owens, B., Jacobson, L. P., Shih, R., Lewis, J., Wiley, D. J., Phair, J. P., Wolinsky, S. M., and Detels, R. (1999). Shorter survival in advanced uman immunodeficiency virus type 1 infection is more closely associated with $\mathrm{T}$ lymphocyte activation than with plasma virus burden or virus chemokine coreceptor usage. J. Infect. Dis. 179, 859-870.

Goonetilleke, N., Liu, M. K., Salazar-Gonzalez, J. F., Ferrari, G., Giorgi, E., Ganusov, V. V., Keele, B. F., Learn, G. H., Turnbull, E. L., Salazar, M. G., Weinhold, K. J., Moore, S., CHAVI Clinical Core B, Letvin, N., Haynes, B. F., Cohen, M. S., Hraber, P., Bhattacharya, T., Borrow, P., Perelson, A. S., Hahn, B. H., Shaw, G. M., Korber, B. T., and McMichael, A. J. (2009). The first T cell response to transmitted/founder virus contributes to the control of acute viremia in HIV-1 infection. J. Exp. Med. 206, 1253-1272.

Grossman, Z., Meier-Schellersheim, M., Sousa, A. E., Victorino, R. M. M., and Paul, W. E. (2002). CD4 T-cell depletion in HIV infection: are we closer to understanding the cause ? Nat. Med. 8, 319-323.

Hansen, S. G. Ford, J. C., Lewis, M. S., Ventura, A. B., Hughes, C. M., Coyne-Johnson, L., Whizin, N., Oswald, K., Shoemaker, R., Swanson, T., Legasse, A. W., Chiuchiolo, M. J., Parks, C. L., Axthelm, M. K., Nelson, J. A., Jarvis, M. A., Piatak, M. Jr., Lifson, J. D., and Picker, L. J. (2011). Profound early control of highly pathogenic SIV by an effector memory T-cell vaccine. Nature $473,523-527$.

Hardy, A. W., Graham, D. R., Shearer, G. M., and Herbeuval, J. P. (2007). HIV turns plasmacytoid dendritic cells ( $\mathrm{pDC}$ ) into TRAIL-expressing killer pDC and down-regulates HIV coreceptors by Toll-like receptor 7-induced IFN-alpha. Proc. Natl. Acad. Sci. U.S.A. 104, 17453-17458.

Hazenberg, M. D., Hamann, D., Schuitemaker, H., and Miedema, F. (2000). T cell depletion in HIV-1 infection: how CD4+ T cells go out of stock. Nat. Immunol. 1,285-289.

Hazenberg, M. D., Otto, S. A, van Benthem, B. H., Roos, M. T., Coutinho, R.A., Lange, J.M., Hamann, D., Prins, M., and Miedema, F. (2003). Persistent immune activation in HIV-1 infection is associated with progression to AIDS. AIDS 17, 1881-1888.

Ho, D. D., Neumann, A. U., Perelson, A. S., Chen, W., Leonard, J. M., and Markowitz, M. (1995). Rapid turnover of plasma virions and CD4+ lymphocytes in HIV-1 infection. Nature 373, 123-126.

Jiang, W., Lederman, M. M., Hunt, P., Sieg, S. F., Haley, K., Rodriguez, B., Landay, A., Martin, J., Sinclair, E., Asher, A. I., Deeks, S. G., Douek, D. C., and Brenchley, J. M. (2009). Plasma levels of bacterial DNA correlate with immune activation and the magnitude of immune restoration in persons with antiretroviral-treated HIV infection. J. Infect. Dis. 199, 1177-1185.

Koot, M., Keet, I. P., Vos, A. H., de Goede, R. E., Roos, M. T., Coutinho, R. A., Miedema, F., Schellekens, P. T., and Tersmette, M. (1993). Prognostic value of human immunodeficiency virus type 1 biological phenotype for rate of $\mathrm{CD} 4+$ cell depletion and progression to AIDS. Ann. Intern. Med. 118, 681-688.

Leslie, A. J., and Goulder, P. J. (2006). HIV escape and attenuation by cytotoxic T lymphocytes. Curr. Opin. HIV AIDS 1, 34-39.

McCune, J. M. (2001). The dynamics of CD4+ T-cell depletion in HIV disease. Nature 410, 974-979.

Medzhitov, R. (2010). Inflammation 2010: new adventures of an old flame. Cell 140, 771-776.

Meier, A., Alter, G., Frahm, N., Sidhu, H., Li, B., Bagchi, A., Teigen, N., Streeck, H., Stellbrink, H. J., Hellman, J., van Lunzen, J., and Altfeld, M. (2007). MyD88dependent immune activation mediated by human immunodeficiency virus type 1-encoded Toll-like receptor ligands. J. Virol. 81, 8180-8191.

Miura, T., Brumme, Z. L., Brockman, M. A., Rosato, P., Sela, J., Brumme, C. J., Pereyra, F., Kaufmann, D. E., Trocha, A., Block, B. L., Daar, E. S., Connick, E., Jessen, H., Kelleher, A. D., Rosenberg, E., Markowitz, M., Schafer, K., Vaida, F., Iwamoto, A., Little, S., and Walker, BD. (2010). Impaired replication capacity of acute/early viruses in persons who become HIV controllers. J. Virol. 84, 7581-7591.

Navis, M., Schellens, I., van Baarle, D., Borghans, J., van Swieten, P., Miedema, F., Kootstra, N., and Schuitemaker, H. (2007). Viral replication capacity as a correlate of HLA B57/B5801-associated nonprogressive HIV-1 infection. J. Immunol. 179, 3133-3143.

Schellens, I. M., Borghans, J. A., Jansen, C. A., De Cuyper, I. M., Geskus, R. B., van Baarle, D., and Miedema, F. (2008). Abundance of early functional HIV-specific CD8+ T cells does not predict AIDS-free survival time. PLoS ONE 3, e2745. doi: 10.1371/journal. pone. 0002745
Sereti, I., Dunham, R. M., Spritzler, J., Aga, E., Proschan, M. A., Medvik, K., Battaglia, C. A., Landay, A. L., Pahwa, S., Fischl, M. A., Asmuth, D. M., Tenorio, A. R., Altman, J. D., Fox, L., Moir, S., Malaspina, A., Morre, M., Buffet, R., Silvestri, G., and Lederman, M. M., ACTG 5214 Study Team. (2009). IL-7 administration drives T cell-cycle entry and expansion in HIV-1 infection. Blood 113, 6304-6314.

Silvestri, G., Sodora, D. L., Koup, R. A., Paiardini, M., O’Neil, S. P., McClure, H. M., Staprans, S. I., and Feinberg, M. B. (2003). Nonpathogenic SIV infection of sooty mangabeys is characterized by limited bystander immunopathology despite chronic highlevel viremia. Immunity 18, 441-452.

Tersmette, M., Gruters, R. A., de Wolf, F., de Goede, R. E., Lange, J.M., Schellekens, P. T., Goudsmit, J., Huisman, H. G., and Miedema, F. (1989). Evidence for a role of virulent human immunodeficiency virus (HIV) variants in the pathogenesis of acquired immunodeficiency syndrome: studies on sequential HIV isolates. J. Virol. 63, 2118-2125.

Wu, X., Yang, Z. Y., Li, Y., Hogerkorp, C. M., Schief, W. R., Seaman, M. S., Zhou, T., Schmidt, S. D., Wu, L., Xu, L., Longo, N. S., McKee, K., O’Dell, S., Louder, M. K., Wycuff, D. L., Feng, Y., Nason, M., Doria-Rose, N., Connors, M., Kwong, P. D., Roederer, M., Wyatt, R. T. Nabel, G. J., and Mascola, J. R. (2010). Rational design of envelope identifies broadly neutralizing human monoclonal antibodies to HIV-1. Science 329, 856-861.

Zhou, T., Georgiev, I., Wu, X., Yang, Z. Y., Dai, K., Finzi, A., Kwon, Y. D., Scheid, J. F., Shi, W., Xu, L., Yang, Y., Zhu, J., Nussenzweig, M. C., Sodroski, J., Shapiro, L., Nabel, G. J., Mascola, J. R., and Kwong, P. D. (2010). Structural basis for broad and potent neutralization of HIV-1 by antibody VRC01. Science 329, 811-817.

Received: 23 May 2011; accepted: 25 May 2011; published online: 23 September 2011

Citation: Miedema F (2011) Grand Challenges in the immunology of HIV and AIDS. Front. Immun. 2:20. doi: 10.3389/fimmu.2011.00020

This article was submitted to Frontiers in HIV and AIDS, a specialty of Frontiers in Immunology.

Copyright $\odot 2011$ Miedema. This is an open-access article subject to a non-exclusive license between the authors and Frontiers Media SA, which permits use, distribution and reproduction in other forums, provided the original authors and source are credited and other Frontiers conditions are complied with. 